\title{
COVID-19 Drug Treatment in China
}

\section{Linzi Fan ${ }^{1} \cdot$ Shuang Jiang ${ }^{1} \cdot$ Xinrong Yang ${ }^{1} \cdot$ Zhibin Wang $^{2} \cdot$ Chunjuan Yang $^{1}$}

Published online: 19 June 2020

(C) Springer Nature Switzerland AG 2020

\begin{abstract}
Purpose of Review An unprecedented outbreak of the novel coronavirus in China (COVID-19) occurred in December 2019, and then engulfed the entire world, presenting a significant and urgent threat to global health. Many research institutes have been involved in the development of drugs and vaccines against COVID-19.

Recent Findings At present, the strategy of new use of old drugs is mainly used to screen candidate drugs against the novel coronavirus (later termed severe acute respiratory syndrome coronavirus 2 (SARS-CoV-2)) and inhibit excessive immune response. Related research has made great progress.

Summary In this review, we summarize the drugs used for COVID-19 treatment in China based on the emerging basic and clinical data. It is hoped that this review will be useful to provide guidance for the prevention, treatment, and control of COVID-19.
\end{abstract}

Keywords COVID-19 $\cdot$ SARS-CoV-2 $\cdot$ Medical treatment $\cdot$ New drug research and development

\section{Introduction}

An outbreak of a series of pneumonia cases associated with a novel coronavirus has been reported in Wuhan, Hubei Province, China, since December 2019 [1-3]. It is highly contagious and has rapidly spread to the entire China and multiple other countries worldwide since then [4-6]. On January 5,

Zhibin Wang

wzbmailbox@hljucm.net

Chunjuan Yang

chunjuanyang@hrbmu.edu.cn

Linzi Fan

felicitafan@163.com

Shuang Jiang

jsjiang111@163.com

Xinrong Yang

yangxinrongx@163.com

1 Department of Pharmaceutical Analysis and Analytical Chemistry, College of Pharmacy, Harbin Medical University, No. 157 Baojian Road, Nangang District, Harbin 150081, Heilongjiang, People's Republic of China

2 Key Laboratory of Chinese Materia Medica (Ministry of Education), Heilongjiang University of Chinese Medicine, Harbin 150040, Heilongjiang, China
2020, Professor Zhang of Fudan University completed virus sequencing and submitted the first novel coronavirus genome sequence to the National Bank of the US National Center for Biotechnology Information (Acc. No. MN908947). After that, this global health threat was officially and internationally named SARS-CoV-2 by the World Health Organization (WHO) on February 11, 2020 [7]. On January 30, 2020, the WHO declared the Chinese outbreak of COVID-19 to be a public health emergency of international concern, which means the outbreak of COVID-19 raised intense attention internationally; all countries around the world should be prepared for a potential global outbreak [8-10]. Up to now, there had been 1,524,334 confirmed cases, 340,335 cured, and 88,468 deaths (as of April 9, 2020). Clinically, most patients developed mild symptoms of dry cough, dyspnea, fever, and bilateral lung infiltrates on imaging [11-13]. Besides, numbers of researches have confirmed that while the mortality rate of the elderly and patients with underlying diseases is high, that of the young is relatively low through the deadliest outbreak of COVID-19 [14].

There are six strains of coronaviruses that are confirmed infectious to humans, which are named for their coronary appearance with positive single-stranded RNA genomes [15]. Similar to SARS and MERS, SARS-CoV-2 is a kind of highly pathogenic coronavirus that could cause severe respiratory illness and even death [16]. However, SARS-CoV-2 has higher transmissibility from human to human 
comparatively, which makes humans vulnerable to infection and makes it harder to get this outbreak under control [17-19].

As the epidemic is getting worse, the control of COVID-19 presents multiple challenges in the short term [20]. Nevertheless, no specific antiviral medicine is available either to treat or to prevent the aggravation of COVID-19 [21, 22]. More potent antiviral drugs are urgent to be developed [23]. It usually takes about 12 to 15 years for a new drug transitioning from development to market, which is a fairly long process. Therefore, it is not feasible to study antinovel coronavirus drugs from the beginning to get a direct effect on the prevention and control of this outbreak. Only by adopting the strategy of "old drugs for new use," that is, finding effective drugs against novel coronavirus from existing drugs on the market, making it be rapidly applied to clinical practice [24, 25]. COVID-19's therapeutic strategies mainly relied on the experience of clinicians [26, 27]. Up to now, some medicines are confirmed clinically to be effective in eliminating SARSCoV-2 and improving symptoms [28, 29]. Among them, traditional Chinese medicines have received broad adoption, especially in treating cases of mild symptoms [30, 31]. In this review, we summarized the drugs used for COVID-19 treatment in China based on the emerging basic and clinical data. It is hopeful that this review will be useful to provide guidance for the prevention and control of COVID-19.

\section{Traditional Chinese Medicine}

Although there is no specific medicine recommended to prevent or treat the novel coronavirus to date, when the outbreak started, Chinese medicine (CM) approaches including oral administration of preventive herbal formulae, wearing $\mathrm{CM}$ sachets, and indoor herbal medicine fumigation were recommended for prevention and treatment and have shown pretty good effects $[32,33]$. Under the guidance of clinical experience, the treatment for COVID-19 was divided into medical observation period and clinical treatment period (confirmed cases). The clinical treatment period (confirmed cases) is further stratified into four manifestations including mild case (cold-damp constraint in the lung pattern or damp-heat accumulation in the lung pattern), moderate case (damp-toxin constraint in the lung pattern or cold-damp obstructing the lung pattern), severe case (epidemic toxin blocking the lung pattern or blazing of both Qi and Ying patterns), and critical case (internal blockage and external desertion pattern) followed by a rehabilitation stage (lung and spleen qi deficiency patterns or deficiency of both qi and yin patterns). Depending on the patient's pathological condition, different medications or prescriptions were used at different stages [30, 34]. At present, a total of 23 different Chinese medicines are recommended nationwide for the treatment of mild, severe, and critical symptoms [35]. According to prescriptions and standards, under the guidance of traditional Chinese medicine theory, Chinese medicines were made into certain dosage forms, which could be directly used for the prevention and treatment of diseases [36-42]. Those Chinese medicine formulation used on COVID-19 are listed in Table 1.

\section{Chemical Medicine}

\section{Lopinavir/Ritonavir}

Lopinavir/ritonavir tablets (trade name: Cleeve) are broadspectrum antiviral drugs developed by AbbVie Inc., which was first approved by the European Union in 2001 [43, 44]. It is a type of human immunodeficiency virus (HIV) protease inhibitor that can block the cleavage of Gag-Pol precursor protein into mature protein, which eventually leads to the production of immature and non-infectious virus particles [45, 46]. It has been confirmed that ritonavir is an active peptidomimetic inhibitor against HIV-1 and HIV-2 aspartyl proteases. The enzyme cannot cleave the Gag-Pol precursor protein by inhibiting HIV protease which could lead to the formation of immature forms of HIV particles and prevent a new round of infection [47]. Currently, in vitro studies have shown that lopinavir/ritonavir can inhibit the replication of Middle East respiratory syndrome coronavirus (MERS-CoV) and severe acute respiratory syndrome coronavirus (SARS$\mathrm{CoV}$ ) to exert antiviral effects [48]. Based on that, lopinavir/ ritonavir has been recommended for the clinical treatment of COVID-19 in China. According to the advantages of lopinavir/ritonavir in antiviral therapy, it is suggested that lopinavir/ritonavir should use in the early period of antiviral treatment to improve clinical symptoms and reduce viral load. The oral dosage is recommended once a day $(800 \mathrm{mg} / 200 \mathrm{mg})$ that may increase treatment compliance, reduce adverse reactions, control the spread through urine and feces, and hinder the spread of the epidemic [32, 49]. However, the latest research has reported that lopinavir/ritonavir treatment did not significantly accelerate clinical improvement, reduce mortality, or diminish throat viral RNA detectability in patients with COVID-19 [50]. Besides, it should be noted that lopinavir/ ritonavir is an inhibitor of liver P450 isoenzyme CYP3A. When it is combined with drugs that are mainly metabolized by CYP3A, it may lead to increased blood concentration of the combining drugs, which increases the adverse reaction.

\section{Ribavirin}

Ribavirin is a synthetic nucleoside antiviral drug with broadspectrum antiviral activity, which inhibits both DNA and RNA viruses and widely used for the treatment of SARS and MERS [43, 51-53]. It was recommended that the combined use of ribavirin and $\alpha$-interferon or lopinavir, $500 \mathrm{mg} /$ 


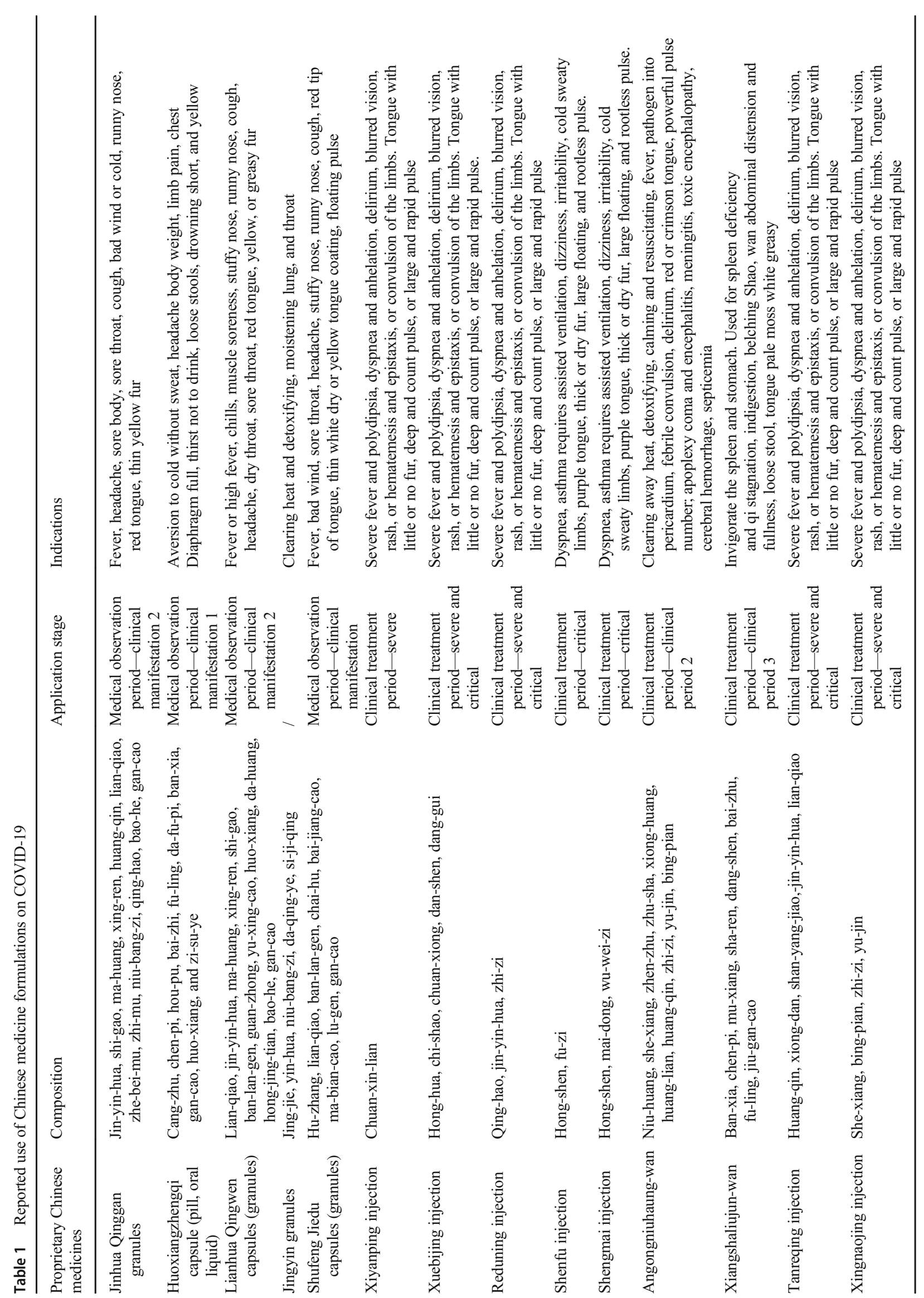


time for adults with 2 to 3 intravenous injections per day, could control and improve patient's condition, but the therapeutic process should be limited to 10 days [32]. Notably, patients with contraindications should be excluded before clinical application for the reason that the incidence of adverse reactions of ribavirin is high and the individualized differences are obvious [54]. Studies on the effect of ribavirin in vitro showed that ribavirin could reduce viral infection [55]. However, the effectiveness and safety of ribavirin for COVID-19 still need further clinical trials to confirm. Medical workers should carefully and comprehensively evaluate the patient's various indicators to ensure the safety of patients' medication.

\section{Arbidol}

Arbidol is a non-nucleoside antiviral drug developed by the research center for pharmaceutical chemistry of the Soviet Union. Arbidol exerts an antiviral effect by inhibiting the fusion of the viral lipid membrane with the host cell to block the replication of the virus [56, 57]. It is active against many enveloped and non-enveloped viruses and has an interferoninducing effect [58]. It has been found that 10-30 $\mu \mathrm{mol}$ of arbidol could effectively inhibit SARS-CoV-2 proliferation by 60 times compared with a drug-untreated control group and significantly inhibit the pathological effects of viruses in vitro $[54,59]$.

\section{Remdesivir}

Remdesivir is a nucleoside drug and an RNA polymerase (RdRp) inhibitor which was developed by Gilead Sciences in the USA [60, 61]. Accumulating evidence indicates that remdesivir could inhibit virus replication and play an antiviral role through blocking the synthesis of negative-strand RNA by inhibiting SARS-CoV-2 RdRp, subgenomic mRNA, and subviral genomic RNA $[62,63]$. Remdesivir has shown good anti-MERS-CoV and anti-SARS-CoV activities in vitro and in animal models [64] and has anti-SARS-CoV-2 activity in vitro, indicating it could be used as a potential antiSARS-CoV-2 drug [65]. On January 31, 2020, the prestige medical journal "New England Medical Journal" (NEJM) reported the diagnosis and treatment process of the first SARSCoV-2 infected patient in the USA, showing that remdesivir has a certain role in the treatment $[25,54,66]$. Cell research published an article stating that among the six antiviral drugs tested, remdesivir had the strongest inhibitory effect of COVID-19 in vitro $\left(\mathrm{EC}_{50}=0.77 \mu \mathrm{mol} / \mathrm{L}\right)$ [32]. Currently, remdesivir's clinical trials have been officially launched in China that a total of 761 patients are planned to be included in this study.

\section{Favipiravir}

Favipiravir is a wide-spectrum nucleoside antiviral drug developed by FUJIFILM Toyama Chemical Co., Ltd. [67]. It is a precursor drug that could be metabolized into the active metabolite favipiravir-ribofuranosyl-5'-triphosphate (favipiravir$\mathrm{rtp}$ ) in vivo, which has an inhibitory effect on the RNA virus RdRp. The drug's initial indication was against influenza [68]. But subsequent studies have shown that the drug has inhibitory activity against almost all RNA viruses, such as West Nile virus, yellow fever virus, enterovirus, and Ebola virus [69-72]. On February 15, 2020, favipiravir tablets were marketed in China, and the indication was approved for the treatment of new or recurrent epidemics in adults. Thus, favipiravir became a potential drug for treatment of COVID19 patients [73]. In a small-scale clinical trial of COVID-19, favipiravir has shown promising efficacy and low adverse reactions. It has been shown that favipiravir is effective against SARS-CoV-2 $\left(\mathrm{EC}_{50}=61.88 \mu \mathrm{mol} / \mathrm{L}\right)[32]$.

\section{Darunavir}

Darunavir is an inhibitor of protease dimerization and catalytic activity of HIV-1 [74, 75]. It can selectively inhibit the cleavage of HIV encoded gag-pol precursor protein in virus infected cells, thus blocking the formation of mature infectious virus particles [76, 77]. Clinically, darunavir is mainly used as a drug for AIDS. On February 4, 2020, it was announced that darunavir could significantly inhibit the replication of the virus at concentration of $300 \mu \mathrm{mol} / \mathrm{L}[32,54]$.

\section{Emtricitabine and Denofovir Alafenamide}

Emtricitabine is a nucleoside reverse transcriptase inhibitor which is used in AIDS treatment [78, 79]. It blocks the reverse transcription process of HIV by inhibiting reverse transcriptase and can also effectively inhibit hepatitis B virus (HBV) reverse transcription process $[77,80]$. It has been reported that the combination of emtricitabine and denofovir alafenamide in clinical trial for the treatment of COVID-19 was applied with great therapeutic effects [32].

\section{Chloroquine Phosphate}

Chloroquine phosphate is mainly used in the treatment of malaria and rheumatism in clinical [81-83]. Numerous studies have presented that it has broad-spectrum antiviral effect [84]. Recently, it has been found that chloroquine phosphate could effectively inhibit the infection of coronavirus at the cellular level [85-87]. It has been recommended for antiviral treatment of the COVID-19 as well [88]. 


\section{Hydroxychloroquine}

Hydroxychloroquine was developed as an antimalarial drug and has been used for the treatment of rheumatoid arthritis and lupus erythematosus [89-91]. Due to its antiviral activity, hydroxychloroquine has also been used as an adjuvant therapy for AIDS [92-94]. It has been confirmed that hydroxychloroquine also has therapeutic effect against Ebola virus and dengue virus in in vitro studies [95]. Recently, it has been reported that some COVID-19 patients benefited from the treatment with hydroxychloroquine [96-99]. Moreover, its effect for virus elimination could be reinforced by azithromycin [97].

\section{Biological Medicine}

\section{Interferon a}

Interferon (IFN) is a kind of multifunctional cytokine family with broad-spectrum antiviral, antiproliferative, and immunomodulatory activities. According to different binding receptors, it can be divided into type I, type II, and type III. Among them, type II IFN (mainly $\alpha / \beta$ IFN) plays an important role in the control of virus infection. Naturally, IFN- $\alpha$ is a very important immune protective cytokine in human response to virus infection [100, 101]. It could induce the same cell to produce antiviral protein and limit the further replication and spread of the virus $[102,103]$. Moreover, IFN- $\alpha$ has been recommended to be applied in the treatment of COVID-19 recently [32].

\section{Tocilizumab Injection}

Tocilizumab injection is a recombinant humanized monoclonal antibody against human IL-6 receptor, which specifically binds to soluble and membranous IL-6 receptor to block signal transduction, thus inhibiting the activity of IL-6 receptor and achieving the goal of treating rheumatoid arthritis [104-106]. IL-6R plays an important role in the occurrence and development of some inflammatory and autoimmune diseases. As an activator of IL-6, sIL-6R can enhance the sensitivity of cells to IL-6 [107]. It has been found that as an antagonist of cytokine interleukin-6 (IL-6), tocilizumab injection is likely to block cytokine storm and thus prevent COVID-19 patients from turning to severe and critical diseases [108]. Tocilizumab injection has been recommended as a treatment for COVID-19 by researchers at University of Science and Technology of China.

\section{Glucocorticoids}

Glucocorticoid is an extremely important regulatory molecule in the human body [109]. It plays an important role in regulating the body's development, growth, metabolism, and immune function. It is the most important regulatory hormone in the body's stress response, and it is also the most widely used and effective antiinflammatory and immunosuppressive agent in clinical practice $[110,111]$. During the treatment of COVID-19, it is recommended to be used for severe cases with high inflammatory response or children with acute respiratory distress syndrome $[32,112]$. However, the side effects of glucocorticoids are severe; WHO recommends that glucocorticoids are not suitable for the routine treatment of COVID19 except in clinical trials $[11,113,114]$.

\section{Convalescent Plasma Therapy}

Currently, the convalescent plasma therapy has been in the process of promotion; some patients' clinical indicators and symptoms have been improved [32]. There have been a large number of people who have recovered from coronavirus infection, donating valuable serum containing immunoglobulin which seems better than trying to produce large amounts of monoclonal antibodies in the laboratory. However, using antibodies to treat COVID-19 has some obvious problems such as limited sources of therapeutic plasma, different concentrations and activities of antibodies in human plasma of various sources, and non-neutralizing antibodies in plasma that may contribute to cytokine storms and other safety risks. Therefore, the convalescent plasma therapy is only used on a small scale, while large-scale use still needs to wait until we understand the clinical application effect and adverse reactions. The safety and efficacy of convalescent plasma transfusion in SARS-CoV-2-infected patients should be studied within the context of a well-designed clinical trial. In the absence of vaccines and specific therapeutic drugs, the recovery plasma therapy is still an exploratory treatment. The current diagnosis and treatment scheme is recommended to try in severe patients and closely monitor the possible risks [115].

\section{Other Biological Medicine}

There are also other biological medicines on COVID-19 such as human immunoglobulin and intestinal microecological regulator. Some researchers in China have suggested that human immunoglobulins can be selectively used to treat critically patients. Intravenous immunoglobulin in large doses could be used for severe systemic inflammatory response syndrome [11]. It has been suggested that intestinal microecological regulator could maintain intestinal microecological balance and prevent secondary bacterial infection [32].

\section{Perspective}

As for a new emerging acute infectious disease caused by SARS-CoV-2, there are still no specific antiviral drugs. All 
options for its prevention and treatment are based on previous experience in the treatment of SARS, MERS, or other new influenza viruses. Active treatment based on the patient's symptoms is still the main direction of treatment. Up to now, China has made a great breakthrough in fighting against COVID-19, but the situation outside China is not optimistic. The Chinese Health Commission has established several versions of diagnosis and treatment plans on COVID-19, which was formulated in a short time by professionals in various fields. But it is just a temporary solution at present. Since these drugs were not developed for the treatment of COVID-19, the clinical therapeutic effect is surely limited. Besides, the efficacy and safety of involved medicines still need to be confirmed in further clinical treatment and research. Even though those medicines we used have certain therapeutic effect, it is still urgent for medical researchers to carry on the research and development of specific medicine and vaccine according to the infection mechanism and characteristic structure of new crown virus. What is more, an effective mechanism for drug development of coronavirus should be established.

Currently, the enthusiasm for COVID-19 drug research runs high, but whether long-term scientific research can persist after the epidemic is a bit more in doubt. The isolation and structure analysis of various coronaviruses have been completed in early period, but there is still no specific drug for each coronavirus in the world. The reasons are as follows: firstly, the replication mutation rate of the virus is very high, and it is easy to produce drug-resistant strains. Secondly, after the acute infectious period of a novel coronavirus, the patient is likely to have developed a corresponding durable immunity. However, compared with the transient infection of virus epidemic, the new drug development cycle is fairly a long time, which is not suitable for the development of coronavirus drugs economically. Therefore, the joint efforts of government departments and drug research and development departments are needed to achieve a breakthrough in a short period of time, for accumulating experience of the possible future coronavirus epidemic.

\section{Conclusions}

The drugs used for COVID-19 treatment in China based on the emerging basic and clinical data were summarized above. Among them, Chinese medicines have received broad adoption, especially in treating cases of mild symptoms. There is still a lot for us to do in the face of COVID-19. It is hoped that this review will be useful to provide guidance for the prevention and control of COVID-19.

Funding Information This work was supported by the Scientific Research Project of National Natural Science Foundation of China (Nos. 81872979 and 81973439).

\section{Compliance with Ethical Standards}

Conflict of Interest The authors declare no conflicts of interest relevant to this manuscript.

Human and Animal Rights and Informed Consent This article does not contain any studies with human or animal subjects performed by any of the authors.

\section{References}

1. Ksiazek TG, Erdman D, Goldsmith CS, Zaki SR, Peret T, Emery $\mathrm{S}$, et al. A novel coronavirus associated with severe acute respiratory syndrome. N Engl J Med. 2003;348(20):1953-66.

2. Lu H, Stratton CW, Tang YW. Outbreak of pneumonia of unknown etiology in Wuhan, China: the mystery and the miracle. J Med Virol. 2020;92(4):401-2.

3. Zhu N, Zhang D, Wang W, Li X, Yang B, Song J, et al. A novel coronavirus from patients with pneumonia in China, 2019. N Engl J Med. 2020;382(8):727-33.

4. Bastola A, Sah R, Rodriguez-Morales AJ, Lal BK, Jha R, Ojha $\mathrm{HC}$, et al. The first 2019 novel coronavirus case in Nepal. Lancet Infect Dis. 2020;20(3):279-80.

5. Holshue ML, DeBolt C, Lindquist S, Lofy KH, Wiesman J, Bruce $\mathrm{H}$, et al. First case of 2019 novel coronavirus in the United States. N Engl J Med. 2020;382(10):929-36.

6. Livingston E, Bucher K. Coronavirus disease 2019 (COVID-19) in Italy. Jama. 2020;323:1335.

7. Lai CC, Shih TP, Ko WC, Tang HJ, Hsueh PR. Severe acute respiratory syndrome coronavirus 2 (SARS-CoV-2) and coronavirus disease-2019 (COVID-19): the epidemic and the challenges. Int J Antimicrob Agents. 2020;55(3):105924.

8. Guo YR, Cao QD, Hong ZS, Tan YY, Chen SD, Jin HJ, et al. The origin, transmission and clinical therapies on coronavirus disease 2019 (COVID-19) outbreak - an update on the status. Mil Med Res. 2020;7(1):11.

9. Salzberger B, Glück T, Ehrenstein B. Successful containment of COVID-19: the WHO-report on the COVID-19 outbreak in China. Infection. 2020;48(2):151-3.

10. Silverstein WK, Stroud L, Cleghorn GE, Leis JA. First imported case of 2019 novel coronavirus in Canada, presenting as mild pneumonia. Lancet. 2020;395((10225)):734.

11. Wang D; Hu B; Hu C; Zhu F; Liu X; Zhang J; Wang B; Xiang H; Cheng Z; Xiong Y; Zhao Y; Li Y; Wang X; Peng Z Clinical characteristics of 138 hospitalized patients with 2019 novel coronavirus-infected pneumonia in Wuhan, China. Jama 2020.

12. Chen N, Zhou M, Dong X, Qu J, Gong F, Han Y, et al. Epidemiological and clinical characteristics of 99 cases of 2019 novel coronavirus pneumonia in Wuhan, China: a descriptive study. Lancet. 2020;395(10223):507-13.

13. Henry BM; Vikse J Clinical characteristics of Covid-19 in China. N Engl J Med 2020, 382.

14. Xu Z, Shi L, Wang Y, Zhang J, Huang L, Zhang C, et al. Pathological findings of COVID-19 associated with acute respiratory distress syndrome. Lancet Respir Med. 2020;8:420-2.

15. Yin Y, Wunderink RG. MERS, SARS and other coronaviruses as causes of pneumonia. Respirology. 2018;23(2):130-7.

16. Liu Y; Gayle AA; Wilder-Smith A; Rocklöv J The reproductive number of COVID-19 is higher compared to SARS coronavirus. J Travel Med 2020, 27, (2).

17. Chan JF, Yuan S, Kok KH, To, K. K, Chu H, Yang J, et al. A familial cluster of pneumonia associated with the 2019 novel 
coronavirus indicating person-to-person transmission: a study of a family cluster. Lancet. 2020;395(10223):514-23.

18. Phan LT, Nguyen TV, Luong QC, Nguyen TV, Nguyen HT, Le $\mathrm{HQ}$, et al. Importation and human-to-human transmission of a novel coronavirus in Vietnam. N Engl J Med. 2020;382(9):872-4.

19. Li Q, Guan X, Wu P, Wang X, Zhou L, Tong Y, et al. Early transmission dynamics in Wuhan, China, of novel coronavirusinfected pneumonia. N Engl J Med. 2020;382(13):1199-207.

20. Yuen KS, Ye ZW, Fung SY, Chan CP, Jin DY. SARS-CoV-2 and COVID-19: the most important research questions. Cell Biosci. 2020;10:40.

21. Patel A, Jernigan DB. Initial Public Health Response and Interim Clinical Guidance for the 2019 Novel coronavirus outbreak United States, December 31, 2019-February 4, 2020. MMWR Morb Mortal Wkly Rep. 2020;69(5):140-6.

22. Baden LR, Rubin EJ. Covid-19 - the search for effective therapy. N Engl J Med. 2020;382:1851-2.

23. Kupferschmidt K, Cohen J. Race to find COVID-19 treatments accelerates. Science. 2020;367(6485):1412-3.

24. Cunningham AC, Goh HP, Koh D. Treatment of COVID-19: old tricks for new challenges. Crit Care. 2020;24(1):91.

25. $\mathrm{Lu} \mathrm{H}$. Drug treatment options for the 2019-new coronavirus (2019-nCoV). Biosci Trends. 2020;14(1):69-71.

26. Raoult D; Hsueh PR; Stefani S; Rolain JM, COVID-19 therapeutic and prevention. Int J Antimicrob Agents 2020, 105937.

27. Wu J; Li W; Shi X; Chen Z; Jiang B; Liu J; Wang D.; Liu C; Meng Y; Cui L; Yu J; Cao H; Li L, Early antiviral treatment contributes to alleviate the severity and improve the prognosis of patients with novel coronavirus disease (COVID-19). J Intern Med 2020.

28. Mitjà $\mathrm{O}$, Clotet $\mathrm{B}$. Use of antiviral drugs to reduce COVID-19 transmission. Lancet Glob Health. 2020;8:e639-40.

29. Pedersen SF, Ho YC. SARS-CoV-2: a storm is raging. J Clin Invest. 2020;130:2202-5.

30. Ren JL, Zhang AH, Wang XJ. Traditional Chinese medicine for COVID-19 treatment. Pharmacol Res. 2020;155:104743.

31. Guidance for corona virus disease 2019: prevention, control, diagnosis and management. 2020, (People's Medical Publishing House), 146 .

32. Chan KW, Wong VT, Tang SCW. COVID-19: an update on the epidemiological, clinical, preventive and therapeutic evidence and guidelines of integrative Chinese-Western medicine for the management of 2019 novel coronavirus disease. Am J Chin Med. 2020:1-26.

33. Luo H, Tang QL, Shang YX, Liang SB, Yang M, Robinson N, et al. Can Chinese medicine be used for prevention of corona virus disease 2019 (COVID-19)? A review of historical classics, research evidence and current prevention programs. Chin J Integr Med. 2020:1-8.

34. Wan S; Xiang Y; Fang W; Zheng Y; Li B; Hu Y; Lang C; Huang D; Sun Q; Xiong Y; Huang X; Lv J; Luo Y; Shen L; Yang H; Huang G; Yang R, Clinical features and treatment of COVID-19 patients in Northeast Chongqing. J Med Virol 2020.

35. Wang Z, Chen X, Lu Y, Chen F, Zhang W. Clinical characteristics and therapeutic procedure for four cases with 2019 novel coronavirus pneumonia receiving combined Chinese and Western medicine treatment. Biosci Trends. 2020;14(1):64-8.

36. Runfeng L; Yunlong H; Jicheng H; Weiqi P; Qinhai M; Yongxia S; Chufang L; Jin Z; Zhenhua J; Haiming J; Kui Z; Shuxiang H; Jun D; Xiaobo L; Xiaotao H; Lin W; Nanshan Z; Zifeng Y, Lianhuaqingwen exerts anti-viral and anti-inflammatory activity against novel coronavirus (SARS-CoV-2). Pharmacol Res 2020, 104761 .

37. He J, Li Z, Huang W, Guan W, Ma H, Yang ZF, et al. Efficacy and safety of Chou-Ling-Dan granules in the treatment of seasonal influenza via combining Western and traditional Chinese medicine: protocol for a multicentre, randomised controlled clinical trial. BMJ Open. 2019;9(4):e024800.

38. Ma Q; Yu Q; Xing X; Liu S; Shi C; Luo J, San Wu Huangqin Decoction, a Chinese herbal formula, inhibits influenza a/PR/8/34 (H1N1) virus infection in vitro and in vivo. Viruses 2018, 10, (3).

39. Yin J, Ma L, Wang H, Yan H, Hu J, Jiang W, et al. Chinese herbal medicine compound Yi-Zhi-Hao pellet inhibits replication of influenza virus infection through activation of heme oxygenase-1. Acta Pharm Sin B. 2017;7(6):630-7.

40. Zou W, Wang J, Liu Y. Effect of traditional Chinese medicine for treating human immunodeficiency virus infections and acquired immune deficiency syndrome: boosting immune and alleviating symptoms. Chin J Integr Med. 2016;22(1):3-8.

41. Wang L, Yang R, Yuan B, Liu Y, Liu C. The antiviral and antimicrobial activities of licorice, a widely-used Chinese herb. Acta Pharm Sin B. 2015;5(4):310-5.

42. Hsieh YJ, Yen MH, Chiang YW, Yeh CF, Chiang LC, Shieh DE, et al. Gan-Lu-Siao-Du-yin, a prescription of traditional Chinese medicine, inhibited enterovirus 71 replication, translation, and virus-induced cell apoptosis. J Ethnopharmacol. 2016;185:132-9.

43. Totura AL, Bavari S. Broad-spectrum coronavirus antiviral drug discovery. Expert Opin Drug Discovery. 2019;14(4):397-412.

44. Lopinavir. In LiverTox: clinical and research information on druginduced liver injury, National Institute of Diabetes and Digestive and Kidney Diseases: Bethesda (MD), 2012.

45. Canals F, Masiá M, Gutiérrez F. Developments in early diagnosis and therapy of HIV infection in newborns. Expert Opin Pharmacother. 2018;19(1):13-25.

46. Coelho AV; Tricarico PM; Celsi F; Crovella S, Antiretroviral treatment in HIV-1-positive mothers: neurological implications in virus-free children. Int J Mol Sci 2017, 18, (2).

47. Barlow-Mosha L, Angelidou K, Lindsey J, Archary M, Cotton M, Dittmer S, et al. Nevirapine- versus lopinavir/ritonavir-based antiretroviral therapy in HIV-infected infants and young children: long-term follow-up of the IMPAACT P1060 randomized trial. Clin Infect Dis. 2016;63(8):1113-21.

48. Mo Y, Fisher D. A review of treatment modalities for Middle East respiratory syndrome. J Antimicrob Chemother. 2016;71(12): 3340-50.

49. Martinez MA, Compounds with therapeutic potential against novel respiratory 2019 coronavirus. Antimicrob Agents Chemother 2020, 64 .

50. Cao, B.; Wang, Y.; Wen, D.; Liu, W.; Wang, J.; Fan, G.; Ruan, L.; Song, B.; Cai, Y.; Wei, M.; Li, X.; Xia, J.; Chen, N.; Xiang, J.; Yu, T.; Bai, T.; Xie, X.; Zhang, L.; Li, C.; Yuan, Y.; Chen, H.; Li, H.; Huang, H.; Tu, S.; Gong, F.; Liu, Y.; Wei, Y.; Dong, C.; Zhou, F.; Gu, X.; Xu, J.; Liu, Z.; Zhang, Y.; Li, H.; Shang, L.; Wang, K.; Li, K.; Zhou, X.; Dong, X.; Qu, Z.; Lu, S.; Hu, X.; Ruan, S.; Luo, S.; Wu, J.; Peng, L.; Cheng, F.; Pan, L.; Zou, J.; Jia, C.; Wang, J.; Liu, X.; Wang, S.; Wu, X.; Ge, Q.; He, J.; Zhan, H.; Qiu, F.; Guo, L.; Huang, C.; Jaki, T.; Hayden, F. G.; Horby, P. W.; Zhang, D.; Wang, C., A trial of lopinavir-ritonavir in adults hospitalized with severe Covid-19. N Engl J Med 2020.

51. Jordan PC, Stevens SK, Deval J. Nucleosides for the treatment of respiratory RNA virus infections. Antivir Chem Chemother. 2018;26:2040206618764483.

52. Rabaan AA, Alahmed SH, Bazzi AM, Alhani HM. A review of candidate therapies for Middle East respiratory syndrome from a molecular perspective. J Med Microbiol. 2017;66(9):1261-74.

53. Al-Tawfiq JA, Memish ZA. Update on therapeutic options for Middle East respiratory syndrome coronavirus (MERS-CoV). Expert Rev Anti-Infect Ther. 2017;15(3):269-75.

54. Zhang C, Huang S, Zheng F, Dai Y. Controversial treatments: an updated understanding of the coronavirus disease. J Med Virol. 2019:2020. 
55. Feld JJ, Bernstein DE, Younes Z, Vlierberghe HV, Larsen L, Tatsch F, et al. Ribavirin dose management in HCV patients receiving ombitasvir/paritaprevir/ritonavir and dasabuvir with ribavirin. Liver Int. 2018;38(9):1571-5.

56. Blaising J, Polyak SJ, Pécheur EI. Arbidol as a broad-spectrum antiviral: an update. Antivir Res. 2014;107:84-94.

57. Abdelnabi R, Neyts J, Delang L. Towards antivirals against chikungunya virus. Antivir Res. 2015;121:59-68.

58. Teissier E, Penin F, Pécheur EI. Targeting cell entry of enveloped viruses as an antiviral strategy. Molecules. 2010;16(1):221-50.

59. Deng L; Li C; Zeng Q; Liu X; Li X; Zhang H; Hong Z; Xia J, Arbidol combined with LPV/r versus LPV/r alone against corona virus disease 2019: a retrospective cohort study. J Inf Secur 2020.

60. Gordon C J; Tchesnokov EP; Feng JY; Porter DP; Gotte M, The antiviral compound remdesivir potently inhibits RNA-dependent RNA polymerase from Middle East respiratory syndrome coronavirus. J Biol Chem 2020.

61. Tchesnokov EP; Feng JY; Porter DP; Götte M, Mechanism of inhibition of Ebola virus RNA-dependent RNA polymerase by remdesivir. Viruses 2019, 11, (4).

62. Ko WC; Rolain JM; Lee NY; Chen PL; Huang CT; Lee PI; Hsueh $\mathrm{PR}$, Arguments in favour of remdesivir for treating SARS-CoV-2 infections. Int J Antimicrob Agents 2020, 105933.

63. Al-Tawfiq JA; Al-Homoud AH; Memish ZA, Remdesivir as a possible therapeutic option for the COVID-19. Travel Med Infect Dis 2020, 101615

64. Sheahan, T. P.; Sims, A. C.; Leist, S. R.; Schäfer, A.; Won, J.; Brown, A. J.; Montgomery, S. A.; Hogg, A.; Babusis, D.; Clarke, M. O.; Spahn, J. E.; Bauer, L.; Sellers, S.; Porter, D.; Feng, J. Y.; Cihlar, T.; Jordan, R.; Denison, M. R.; Baric, R. S., Comparative therapeutic efficacy of remdesivir and combination lopinavir, ritonavir, and interferon beta against MERS-CoV. Nat Commun 2020, 11, (1), 222.

65. Wang M, Cao R, Zhang L, Yang X, Liu J, Xu M, et al. Remdesivir and chloroquine effectively inhibit the recently emerged novel coronavirus (2019-nCoV) in vitro. Cell Res. 2020;30(3):269-71.

66. Li H, Wang YM, Xu JY, Cao B. Potential antiviral therapeutics for 2019 novel coronavirus. Zhonghua. Zhonghua Jie He He Hu Xi Za Zhi. 2020;43(0):E002.

67. Shiraki K; Daikoku T, Favipiravir, an anti-influenza drug against life-threatening RNA virus infections. Pharmacol Ther 2020, 107512.

68. Goldhill DH, Te Velthuis AJW, Fletcher RA, Langat P, Zambon M, Lackenby A, et al. The mechanism of resistance to favipiravir in influenza. Proc Natl Acad Sci U S A. 2018;115(45):11613-8.

69. Furuta Y, Gowen BB, Takahashi K, Shiraki K, Smee DF, Barnard DL. Favipiravir (T-705), a novel viral RNA polymerase inhibitor. Antivir Res. 2013;100(2):446-54.

70. Furuta Y, Komeno T, Nakamura T. Favipiravir (T-705), a broad spectrum inhibitor of viral RNA polymerase. Proc Jpn Acad Ser B Phys Biol Sci. 2017;93(7):449-63.

71. Guedj, J.; Piorkowski, G.; Jacquot, F.; Madelain, V.; Nguyen, T. H. T.; Rodallec, A.; Gunther, S.; Carbonnelle, C.; Mentré, F.; Raoul, H.; de Lamballerie, X., Antiviral efficacy of favipiravir against Ebola virus: a translational study in cynomolgus macaques. PLoS Med 2018, 15, (3), e1002535.

72. Delang L, Abdelnabi R, Neyts J. Favipiravir as a potential countermeasure against neglected and emerging RNA viruses. Antivir Res. 2018;153:85-94.

73. Dong $\mathrm{L}, \mathrm{Hu} \mathrm{S}, \mathrm{Gao} J$. Discovering drugs to treat coronavirus disease 2019 (COVID-19). Drug Discov Ther. 2020;14(1):58-60.

74. Potard V, Canestri A, Gallien S, Costagliola D. Use of darunavir in HIV-1-infected individuals in routine clinical practice from 2012 to 2016 in France. J Antimicrob Chemother. 2019;74(11): 3305-14.
75. Spagnuolo V, Castagna A, Lazzarin A. Darunavir for the treatment of HIV infection. Expert Opin Pharmacother. 2018;19(10): 1149-63.

76. Llibre, J. M., Development of darunavir over the entire spectrum of HIV infection. Enferm Infecc Microbiol Clin 2018, 36 Suppl 2, 3-9.

77. Deeks ED. Darunavir/cobicistat/emtricitabine/tenofovir alafenamide: a review in HIV-1 infection. Drugs. 2018;78(10): 1013-24.

78. Deeks ED. Bictegravir/emtricitabine/tenofovir alafenamide: a review in HIV-1 infection. Drugs. 2018;78(17):1817-28.

79. Greig SL, Deeks ED. Elvitegravir/cobicistat/emtricitabine/ tenofovir alafenamide: a review in HIV-1 infection. Drugs. 2016;76(9):957-68.

80. Muller JT; Al Khalili Y, Emtricitabine. In StatPearls, StatPearls Publishing. Copyright (C) 2020, StatPearls Publishing LLC: Treasure Island (FL), 2020.

81. Shafi H, Reddy DVS, Khan T, Ranjan R, Srivastava A, Vaishya S, et al. Dehydroascorbate-derivatized chitosan particles for targeting antimalarial agents to infected erythrocytes. Int J Pharm. 2017;524(1-2):205-14.

82. Fukuda MM, Krudsood S, Mohamed K, Green JA, Warrasak S, Noedl H, et al. A randomized, double-blind, active-control trial to evaluate the efficacy and safety of a three day course of tafenoquine monotherapy for the treatment of Plasmodium vivax malaria. PLoS One. 2017;12(11):e0187376.

83. Baruah UK, Gowthamarajan K, Ravisankar V, Karri V, Simhadri PK, Singh V. Optimisation of chloroquine phosphate loaded nanostructured lipid carriers using Box-Behnken design and its antimalarial efficacy. J Drug Target. 2018;26(7):576-91.

84. Paton NI, Lee L, Xu Y, Ooi EE, Cheung YB, Archuleta S, et al. Chloroquine for influenza prevention: a randomised, doubleblind, placebo controlled trial. Lancet Infect Dis. 2011;11(9): 677-83.

85. Yao X; Ye F; Zhang M.; Cui C; Huang B; Niu P; Liu X; Zhao L; Dong E; Song C; Zhan S; Lu R; Li H; Tan W; Liu D, In vitro antiviral activity and projection of optimized dosing design of hydroxychloroquine for the treatment of severe acute respiratory syndrome coronavirus 2 (SARS-CoV-2). Clin Infect Dis 2020.

86. Gao J, Tian Z, Yang X. Breakthrough: chloroquine phosphate has shown apparent efficacy in treatment of COVID-19 associated pneumonia in clinical studies. Biosci Trends. 2020;14(1):72-3.

87. Expert consensus on chloroquine phosphate for the treatment of novel coronavirus pneumonia. Zhonghua Jie He He Hu Xi Za Zhi 2020, 43, (0), E019.

88. Song P, Karako T. COVID-19: real-time dissemination of scientific information to fight a public health emergency of international concern. Biosci Trends. 2020;14(1):1-2.

89. Hydroxychloroquine. In LiverTox: clinical and research information on drug-induced liver injury, National Institute of Diabetes and Digestive and Kidney Diseases: Bethesda (MD), 2012.

90. $\mathrm{Hu} \mathrm{C}, \mathrm{Lu} \mathrm{L}$, Wan JP, Wen C. The pharmacological mechanisms and therapeutic activities of hydroxychloroquine in rheumatic and related diseases. Curr Med Chem. 2017;24(20):2241-9.

91. Schrezenmeier E, Dörner T. Mechanisms of action of hydroxychloroquine and chloroquine: implications for rheumatology. Nat Rev Rheumatol. 2020;16(3):155-66.

92. Plantone D, Koudriavtseva T. Current and future use of chloroquine and hydroxychloroquine in infectious, immune, neoplastic, and neurological diseases: a mini-review. Clin Drug Investig. 2018;38(8):653-71.

93. Shippey EA, Wagler VD, Collamer AN. Hydroxychloroquine: an old drug with new relevance. Cleve Clin J Med. 2018;85(6):459 67. 
94. Khalili H, Dastan F, Dehghan Manshadi SA. A case report of hearing loss post use of hydroxychloroquine in a HIV-infected patient. Daru. 2014;22(1):20.

95. Cao B, Parnell LA, Diamond MS, Mysorekar IU. Inhibition of autophagy limits vertical transmission of Zika virus in pregnant mice. J Exp Med. 2017;214(8):2303-13.

96. Colson P; Rolain JM; Lagier JC; Brouqui P; Raoult D, Chloroquine and hydroxychloroquine as available weapons to fight COVID-19. Int J Antimicrob Agents 2020, 105932.

97. Gautret P; Lagier JC; Parola P; Hoang VT; Meddeb L; Mailhe M; Doudier B; Courjon J; Giordanengo V; Vieira VE; Dupont HT; Honoré S; Colson P; Chabrière E; La Scola B; Rolain JM; Brouqui $\mathrm{P}$; Raoult D, Hydroxychloroquine and azithromycin as a treatment of COVID-19: results of an open-label non-randomized clinical trial. Int J Antimicrob Agents 2020, 105949.

98. Liu J, Cao R, Xu M, Wang X, Zhang H, Hu H, et al. Hydroxychloroquine, a less toxic derivative of chloroquine, is effective in inhibiting SARS-CoV-2 infection in vitro. Cell Discov. 2020;6:16.

99. Sahraei Z; Shabani M; Shokouhi S; Saffaei A, Aminoquinolines against coronavirus disease 2019 (COVID-19): chloroquine or hydroxychloroquine. Int J Antimicrob Agents 2020, 105945.

100. Snell LM, McGaha TL, Brooks DG. Type I interferon in chronic virus infection and cancer. Trends Immunol. 2017;38(8):542-57.

101. Sen N; Sung P; Panda A; Arvin AM, Distinctive roles for type I and type II interferons and interferon regulatory factors in the host cell defense against Varicella-Zoster virus. J Virol 2018, 92, (21).

102. Li HS, Kuok DIT, Cheung MC, Ng MMT, Ng KC, Hui KPY, et al. Effect of interferon alpha and cyclosporine treatment separately and in combination on Middle East respiratory syndrome coronavirus (MERS-CoV) replication in a human in-vitro and exvivo culture model. Antivir Res. 2018;155:89-96.

103. Snyder B, Goebel S, Koide F, Ptak R, Kalkeri R. Synergistic antiviral activity of sofosbuvir and type-I interferons ( $\alpha$ and $\beta$ ) against Zika virus. J Med Virol. 2018;90(1):8-12.

104. Sanmartí R, Ruiz-Esquide V, Bastida C, Soy D. Tocilizumab in the treatment of adult rheumatoid arthritis. Immunotherapy. 2018;10(6):447-64.

105. Ahn SS, Jung SM, Song JJ, Park YB, Park JY, Lee SW. Safety of tocilizumab in rheumatoid arthritis patients with resolved hepatitis
$\mathrm{B}$ virus infection: data from real-world experience. Yonsei Med J. 2018;59(3):452-6.

106. Hashizume M, Tan SL, Takano J, Ohsawa K, Hasada I, Hanasaki A, et al. Tocilizumab, a humanized anti-IL-6R antibody, as an emerging therapeutic option for rheumatoid arthritis: molecular and cellular mechanistic insights. Int Rev Immunol. 2015;34(3): 265-79.

107. Sheppard M, Laskou F, Stapleton PP, Hadavi S, Dasgupta B. Tocilizumab (Actemra). Hum Vaccin Immunother. 2017;13(9): 1972-88.

108. Jones SA, Scheller J, Rose-John S. Therapeutic strategies for the clinical blockade of IL-6/gp130 signaling. J Clin Invest. 2011;121(9):3375-83.

109. Ramamoorthy S, Cidlowski JA. Corticosteroids: mechanisms of action in health and disease. Rheum Dis Clin N Am. 2016;42(1): $15-31$ vii.

110. Meijer OC, Koorneef LL, Kroon J. Glucocorticoid receptor modulators. Ann Endocrinol. 2018;79(3):107-11.

111. Whittier X, Saag KG. Glucocorticoid-induced osteoporosis. Rheum Dis Clin N Am. 2016;42(1):177-89 x.

112. Zhou YH; Qin YY; Lu YQ; Sun F; Yang S; Harypursat V; Tang SQ; Huang YQ; He XQ; Zeng YM.; Li Y; Xu XL; Zhao T; Chen YK, Effectiveness of glucocorticoid therapy in patients with severe novel coronavirus pneumonia: protocol of a randomized controlled trial. Chin Med J 2020.

113. Guo T; Fan Y; Chen M; Wu X; Zhang L; He T; Wang H; Wan J; Wang X; Lu Z, Cardiovascular implications of fatal outcomes of patients with coronavirus disease 2019 (COVID-19). JAMA Cardiol 2020.

114. Hu H; Ma F; Wei X; Fang Y, Coronavirus fulminant myocarditis saved with glucocorticoid and human immunoglobulin. Eur Heart J 2020.

115. Zhang B; Liu S; Tan T; Huang W; Dong Y; Chen L; Chen Q; Zhang L; Zhong Q; Zhang X; Zou Y; Zhang S, Treatment with convalescent plasma for critically ill patients with SARS-CoV-2 infection. Chest 2020.

Publisher's Note Springer Nature remains neutral with regard to jurisdictional claims in published maps and institutional affiliations. 